\title{
Water Parameters and Floristic Composition of African Manatee (Trichechus senegalensis) Habitat in Pandam Wildlife Park, Nigeria
}

\author{
*1ODEWUMI, OS; ${ }^{1}$ AGBELUSI, EA; ${ }^{2}$ OLUSOJI-BELLO, 0 \\ ${ }^{*}$ Department of Ecotourism and Wildlife Management, ${ }^{2}$ Department of Fisheries and Aquaculture Technology, Federal University of \\ Technology, Akure, Nigeria \\ *Corresponding AuthorEmail: owumisunday@gmail.com; osodewumi@futa.edu.ng
}

\begin{abstract}
The study of the physicochemical characteristic and floristic composition of African manatee habitat in Pandam Lake was conducted between 2012 and 2013. The water parameters were tested using standard method while line intercept method was adopted for vegetation survey. Data obtained on the water parameters were analyzed using one-way ANOVA. Plant species diversity index was analyzed using PAST Software. The mean seasonal water surface area increase was $66.12 \pm 5.01$. The mean water depth in the dry season was $2.28 \pm 1.14$ while the wet season value was $4.3 \pm 1.15$. Also the mean water transparency was for wet and dry seasons were $64.02 \pm 4.66$ and $111.18 \pm 4.26$ respectively. The mean pH value was $6.5 \pm 0.14$. Water salinity ranges from $0.00 \mathrm{mg} / 1$ to $0.01 \mathrm{mg} / 1$, mean DO was $6.24 \pm 1.13$, nitrate was $0.08 \pm 0.02$ and mean conductivity of $52.65 \pm 2.12$. A total of 42 plant species from 23 families were recorded in Pandam Lake. The family Poaceae had the highest number of species (22) (30.56\%). The grass species had the highest frequency of 13 while trees recorded the lowest (3). Also there are more perennial species $(\mathrm{n}=28 ; 66.67 \%)$ than annual species $(\mathrm{n}=14 ; 33.33 \%)$. The Shannon diversity index was 3.72. Thirteen species of plants recorded in Pandan Lake during this study were known to provide food for manatees across their range in Africa. All the water parameter values were within the range tolerable by manatee. The Lake have diverse species of plants that manatee can feed on both in the wet and dry seasons. The park management should maintain the integrity of the ecosystem by regulating fishing and other human activities to avoid pollution. The park should be taken over by the Federal government for effective protection of the resources most especially manatee.
\end{abstract}

\section{DOI: https://dx.doi.org/10.4314/jasem.v23i10.22}

Copyright: Copyright (C) 2019 Odewumi et al. This is an open access article distributed under the Creative Commons Attribution License (CCL), which permits unrestricted use, distribution, and reproduction in any medium, provided the original work is properly cited.

Dates: Received: 01 September 2019; Revised: 21 October 2019; 27 October 2019

Keywords: Water quality, vegetation, African manatee, Pandam Lake

In aquatic ecosystems, many factors including radiation, temperature, nutrient availability, physical transport processes, and grazing are known to control the biomass, distribution, and variation of plankton communities (Paerl and Huisman 2008; Lancelot and Muylaert 2011; Sailley et al. 2015). Paerl et al. (2014) opined that human activities (deforestation, land use change, expansion of agriculture and development of industry, urbanization, and increasing wastewater) and global climate change have put remarkable pressure on the ecological conditions and sustainability of many aquatic ecosystems. Human activities have not only increased the quantities of nutrients but also changed forms and proportion of nutrients to the environment which can lead to adverse effects on water quality, such as eutrophication and food web structure (Glibert 2012; Vitousek et al. 2012; Duong et al. 2012; Isbell et al. 2013). Growth, dynamics, distribution, persistence of aquatic species, and the structure of their communities are strongly altered (Paerl et al. 2014) as a result of increasing global temperature, changes in precipitation, evaporation, and runoff. The processing and retention of sediment, nutrients, and pollutants in aquatic systems is accelerated by the presence of aquatic vegetation (Clarke 2002). Numerous studies have shown that macrophytes and algae in marine environments act to reduce ambient concentrations of suspended sediment (Abdelrhman 2003; Moore 2004), nutrients (Moore 2004), and metals (Fritioff and Greger 2003). Macrophytes are important components of the freshwater (aquatic) ecosystem because they enhance the biological complexity and physical structure of habitats which increases biodiversity within the littoral zones (Esteves 1998; Wetzel 2001; Pelicice et al. 2008). In addition, both live and dead materials (detritus) from aquatic macrophyte may serve as food resources for aquatic and terrestrial organisms (Lope et al. 2007). However, in most rivers and lakes the excessive growth of macrophytes may provoke some negative effects (Bini et al. 2005), and it develops into explosively large population only when the environment is altered. Vegetation types and species composition reflect the flooding regime and the chemical quality of the water, whether fresh or saline (Nicole et al., 1994). Species life form categories, prop roots and floating seedlings all help the various plants to survive in such an environment. 
Lake water quality is affected by local and regional drivers, including lake physical characteristics, hydrology, landscape position, land cover, land use, geology, and climate (Read et al., 2015). An altered temperature regime can shift species composition from cool water to warm water species (Bednarek 2001). The distribution, community structure, and variation of plankton are clearly influenced by the combination and interactions between physical, chemical, and biological factors presented in a water body (Sabo et al. 2008; Cisneros et al. 2011; Lancelot and Muylaert 2011) such as rainfall, temperature, light and water discharge (Wehr and Descy 1998; De-Sousa et al. 2016; Bussi et al. 2016), nutrient enrichment, organic matter (De-Domitrovic et al. 2014; Li et al. 2016; Paczkowska et al. 2017; Hoang et al 2018), and grazing (Mariania et al. 2013; Lucas et al. 2016).

The West African manatees (Trichechus senegalensis) are large herbivorous and totally aquatic mammals that fill a unique ecological niche in tropical lakes, rivers and coastal regions around West and part of Central Africa (Keith, 2015). Manatees tend to aggregate in a clumped distribution pattern in preferred habitats with little or no disturbances or in areas that best meet their biotic and abiotic requirements. Consequently, due to patchy distribution of food resources and variation in habitat characteristics, there is unequal distribution of the species and various habitat usages (Nomura and Higashi, 2000). Similar to the West Indian manatee, West African manatees inhabit practically every aquatic habitat that allows them access and meets their thermoregulation requirements of water temperatures greater than $20^{\circ} \mathrm{C}$ for $T$. manatus and where the water temperature is above $18^{\circ} \mathrm{C}\left(64^{\circ} \mathrm{F}\right)$ for $T$. senegalensis (Powell 1996, Dodman et al. 2008). At $20^{\circ} \mathrm{C}$, manatee can function normally. However, at $18-19^{\circ} \mathrm{C}$ feeding becomes irregular and below $16^{\circ} \mathrm{C}$ feeding and other activity ceases. T. senegalensis require sheltered water with access to food and freshwater (Reep and Bonde 2006, Marsh et al. 2012 cited in Keith, 2015). Seasonal movements of African manatees are related to three factors (water current, salinity variation and water level changes), which in-turn is related to dry and rainy seasons in West Africa (Powell, 1996).

The African Manatee is one of the least understood marine mammals in the world, and has recently been shown to be the least studied large mammal in Africa (Trimble and Van Aarde 2010). They are often referred to as the "forgotten" sirenian. Unfortunately, African manatee populations are thought to be small, fragmented, and in continuous decline making the species vulnerable to extinction under IUCN Red list criteria A4cd and C1 (Powell and Akoi, 2006; IUCN, 2016), up-listed from CITES Appendix II to Appendix
I as of the Conference of Parties 16 in March 2013. They are also listed on Appendix I of the Convention on Migratory Species and are protected by national laws in all range states including Nigeria. Pandam Lake was declared a Manatee Sanctuary by BenuePlateau States because manatees seek refuge during the dry season when water level in Benue River is reduced through Deb River (Powell, 1996). Pandam Wildlife Park may be one of the most important habitats for the global conservation of the African manatees. There were no scientific evidence on the impacts of these human activities on the water parameters and their consequences on aquatic organisms like manatee in Pandam Lake. Therefore this study provides such information in Pandam Wildlife Park through the assessment of the physicochemical parameters and floristic composition of manatee habitat for an effective manatee conservation in the park.

\section{MATERIALS AND METHODS}

Study Area: The study was carried out in Pandam Wildlife Park, Plateaus State located in the middle belt region of Nigeria (Figure 1). It lies between Latitude $8^{0} 35^{1} \mathrm{~N}$ and longitude $8^{0} 55^{1} \mathrm{~N}$ and latitude $8^{0} 00^{1} \mathrm{E}$ and longitude $10^{0} 00^{1} \mathrm{E}$. It covers an area of $224 \mathrm{~km}^{2}$ and is located $58 \mathrm{~km}$ along the Lafia-shendam road to the north of Benue River (Ezealor, 2002) and South of Plateau state (Akosim, 2007) in Quanpan local government area. It is bounded on the East by Namu and Kuagarda, on the west and north by Dep River and in the South by Aningo and Pandam communities (Akosim, 2007). The entire area is drained by Dep and Li Rivers and joins to make a Y-shape before emptying into Benue River. The land slopes gradually south wards and form a basin - "Pandam lake" wetland complex of approximately $22 \mathrm{~km}$. The entire park lies within the guinea savannah eco-zone. Thus the vegetation of the park is typical Sudan-Guinea savannah with gallery forest in riparian areas. Pandam Wildlife Park is managed by the Plateau state Tourism Corporation. The wet season lasts from April to October and annual rainfall is 1,000-1,500 $\mathrm{mm}$.

Determination of Water Parameters: Four sampling stations (One station in each of the two streams that supplies water into the lake (I and II), one in the centre/middle of the lake (III) and one station at the exit point (manatee stream) (IV)) were selected to reflect the lentic and lotic nature of the lake as well as influence of the sources of water entering the lake. The parameters investigated include water; temperature, level (depth), surface area, transparency (turbidity), current/velocity, Dissolve Oxygen, salinity and $\mathrm{pH}$. These parameters were investigated both during the rainy and dry seasons for two years (2012-2013). 
Water level was measured using a wooden pole graduated in $\mathrm{cm} / \mathrm{m}$ at three points for each of the four stations. The wooden pole was lowered from a canoe into the water until it rest on the floor of the lake. The depth was then read off the calibrated rope. Water transparency (Turbidity) was measured using a standard Secchi disc having a diameter of $20 \mathrm{~cm}$ with black and white quarters. The Secchi disc was lowered into the water and the depth at which the disc becomes invisible was recorded. It was also gradually withdrawn from the water and the depth at which it becomes visible recorded. The transparency of the water at that point was calculated as the mean of the two readings for each point sampled. Water Temperature $\left(\mathrm{T}^{\mathrm{O}} \mathrm{C}\right)$ and $\mathrm{pH}$ were determined using a high accuracy pen type $\mathrm{pH}$ meter with Temperature display (pH-009 model) (battery operated). The $\mathrm{pH}$ meter was dipped into the water to a graduated level and the $\mathrm{pH}$ and Temperature values displayed were recorded. Water Temperature was measured at $9.00 \mathrm{hr}$ once in a month. Dissolve oxygen was measured using modified Winkler azide method. Conductivity/salinity was determined by Hanna multirange conductivity/salinity meter model H18033 while nitrate and phosphate was determined using Hach Spectrophotometer model DREL5. Three points each were used at the four locations for all the measurements. The samples collected were chemically fixed in the field itself for measuring dissolved oxygen and analysed on the same day in the laboratory. All the parameters were collected in the morning hours. Seasonal change in water surface area was determined by noting the area covered by water during the peak of the wet season and the peak of the dry season. Then the average distance value (from the dry season point and rainy season point) obtained was recorded. Water velocity was determined by recording the time it took a float to cover a predetermined distance $(30 \mathrm{~m})$ using a stopwatch. This was done five times at each of the four locations.

Vegetation Sampling: A line intercept sampling method was used, following Kent and Coker (1996). A rope (nylon type), that is $100 \mathrm{~m}$ long and calibrated at $1 \mathrm{~m}$ interval was used and all species intercepting or touching the tape were recorded. Plant species that are emergent, submerged, floating, and at the bank of the river along the established transect lines were identified and recorded. Any plant species present but not counted were identified and recorded to get the actual species composition of the Pandam Lake. A $1 \mathrm{~m}$ $\mathrm{x} 1 \mathrm{~m}$ quadrat was then laid at $5 \mathrm{~m}$ interval to facilitate a complete littoral and open water plant species data collection. Herbaceous and woody species within each transect were also identified to species level according to Hutchinson and Dalziel (1954-1972). Also, morphological and biological types (grass, tree, herb, shrub and others (fern, creeper, submerged, free floating etc.) and their percentages estimated relative to the total amount of all vegetation forms (Lathourder et al, 2009). Specimens of unknown plants were collected, labelled, photograph taken and then later used a hand book of West Africa weeds for identification.

Plant species diversity index was calculated using Shannon-Weiner Diversity Index written as:

$\mathrm{H}^{\prime}=-\sum_{i=1}^{S}(P i \ln P i) \quad 1$

Where $\mathrm{H}^{1}=$ index; $\mathrm{Pi}=$ the proportion of plants; $\ln =$ natural logarithms; $\sum=$ summation.

Statistical Analysis: Data obtained were described using graphs, charts, tables, percentages and frequencies. Data on the physicochemical parameters in the four stations were analyzed using one way ANOVA to test for significant difference. Plant species diversity indices were determined using PAST ((Paleontological statistics software package for education and data analysis) statistical software [v. $16]$.

\section{RESULTS AND DISCUSSION}

Physicochemical characteristics of Pandam Lake: The mean physico- chemical characteristics of Pandam Lake collected during the field survey (Table 1) put the mean water surface increase at $66.12 \pm 5.01 \mathrm{~m}^{2}$, water depth $(4.3 \pm 1.15 \mathrm{~m}$ and $2.28 \pm 0.41 \mathrm{~m})$ for wet and dry seasons respectively, Transparency $(64.02 \pm 4.66 \mathrm{~cm}$ and $111.18 \pm 4.26 \mathrm{~cm})$ in the wet and dry seasons respectively, $\mathrm{pH}$ was $6.57 \pm 0.14$, Temperature $\left(27.38 \pm 1.05^{\circ} \mathrm{C}\right)$, Dissolve Oxygen (6.24 \pm 1.13$)$, nitrate $(0.08 \pm 0.02)$, conductivity $(52.65 \pm 2.12)$ and salinity $(0.0001)$. The result further showed that station IV had the highest mean seasonal water surface area increase $(72.79 \mathrm{~m} \pm 7.47)$ followed by station III with a mean of $67.10 \mathrm{~m} \pm 16.70$ while the lowest mean seasonal increase in water surface area was recorded in station I $(61.79 \mathrm{~m} \pm 13.34)$. However, there was no significant difference $(\mathrm{p}=0.98002)$ in the mean seasonal water surface area increase within the four locations. Station III was the deepest with a depth of $2.87 \mathrm{~m} \pm 0.34$ and $6.01 \mathrm{~m} \pm 0.01$ in the dry and wet seasons respectively while station IV was shallower than others $(1.94 \mathrm{~m} \pm 0.4-3.54 \mathrm{~m} \pm 0.12$ for dry and wet seasons respectively). Test of homogeneity showed no significant difference $(p>0.05)$ in the water temperature recorded for the four locations. 
Table 1: Mean water parameters of Pandam Lake recorded during the survey

\begin{tabular}{llllll} 
Water Characteristics & Mean & I & II & III & IV \\
\hline Seasonal increase in water surface area & & & & & \\
$\left(\mathrm{m}^{2}\right)$ & $66.12 \pm 5.01$ & $61.79 \pm 13.34$ & $62.79 \pm 12.64$ & $67.10 \pm 16.70$ & $72.79 \pm 7.47$ \\
Water depth (m) (wet) & $4.30 \pm 1.15$ & $3.72 \pm 0.01$ & $3.94 \pm 0.19$ & $6.01 \pm 0.01$ & $3.54 \pm 0.12$ \\
Water depth (m) (dry) & $2.28 \pm 0.41$ & $2.1 \pm 0.1$ & $2.19 \pm 0.06$ & $2.87 \pm 0.34$ & $1.94 \pm 0.40$ \\
Water transparency (cm) (wet) & $64.02 \pm 4.66$ & $60.82 \pm 0.41$ & $64.81 \pm 2.36$ & $70.29 \pm 2.14$ & $60.14 \pm 0.02$ \\
Water transparency (cm) (dry) & $111.18 \pm 4.26$ & $109.17 \pm 11.02$ & $110.18 \pm 9.97$ & $117.41 \pm 5.04$ & $107.94 \pm 8.52$ \\
Water acidity (pH & $6.57 \pm 0.14$ & $6.74 \pm 0.01$ & $6.51 \pm 0.01$ & $6.60 \pm 0.02$ & $6.42 \pm 0.01$ \\
Salinity (mg/l) & 0.0001 & 0.01 & 0.01 & 0 & 0 \\
Water Temperature ( $\left.{ }^{\circ} \mathrm{C}\right)$ & $28.4 \pm 1.05$ & $28.73 \pm 1.57$ & $28.75 \pm 1.36$ & $29.25 \pm 0.46$ & $26.87 \pm 1.35$ \\
Nitrate (mg/ & $0.08 \pm 0.02$ & 0.069 & 0.072 & 0.101 & 0.072 \\
Dissolved Oxygen $(\mathrm{mg} / 1$ & $6.24 \pm 1.13$ & 6.68 & 6.75 & 6.98 & 4.55 \\
Conductivity (um/cm) & $52.65 \pm 2.12$ & 52.4 & 51.6 & 50.9 & 55.7 \\
\hline
\end{tabular}

In general, West African manatees seemed to prefer those areas that had deep pools for refuge during the dry season (Powell, 1996). The mean water depth values which range from $1.94 \pm 0.4 \mathrm{~m}$ to $6.01 \pm 0.01 \mathrm{~m}$ in the dry and wet seasons were within the tolerable mean depth for manatees activities (resting and non-resting) as reported by Bacchus et al., (2009) that the mean water depth for Trichechus manatus manatus in the Drawned Cayne at Belize was $3.5 \pm 0.30 \mathrm{~m}$ (resting holes) $2.0 \pm 0.12 \mathrm{~m}$ (non-resting hole areas). This explains why manatees were seen utilizing all the four locations in the Lake according to Odewumi, et al., (2017). Water transparency values which ranged from $62.12 \mathrm{~cm} \pm 2.14$, to $125.23 \mathrm{~cm} \pm 9.97$ for wet and dry seasons was not too low for manatee survival which could be attributed to the extent of vegetation cover along the shoreline thereby filter sediments before entering the Lake. Apart from the fact that this factor increased the visibility of manatees while in the water, it also allowed high contrast with the mud cloud generated by manatees as they moved. The $\mathrm{pH}$ range $(6.42-6.74)$ recorded were within the range reported by Egwali et al. (2018) (5.95 $\pm 0.24-7.23 \pm 0.05)$. This indicated that the water was not acidic (i.e it is tending towards being alkaline) (Esenowo et al., 2014) which was not harmful to manatee and other aquatic organisms in the Lake. Water salinity values which ranged from $0 \mathrm{mg} / \mathrm{l}-0.01 \mathrm{mg} / \mathrm{l}$ fell within the value obtained by Akoi (2004). High level of nitrites can cause serious illness to both wildlife and humans, The nitrate values between $0.069 \mathrm{mg} / 1$ and $0.101 \mathrm{mg} / \mathrm{l}$ obtained in this study is within the acceptable level in surface water for aquatic organisms and plant growth as reported by Marschner, (1995); Bruning-Fann and Kaneene, (1993) that acceptable nitrate levels for drinking water have been established as $10 \mathrm{mg} / \mathrm{l}$. and that unpolluted water generally has a nitrate reading of less than $1.0 \mathrm{mg} / 1$.. This is due to the fact that farming activities and waste that can increase the nitrate level is prohibited in the area. The DO level recorded was also within the range recorded by Egwali et al. (2018) $(6.52 \pm 0.22-7.77 \pm 2.41)$ for African manatee in
Nigeria. This is also related to the normal nitrate level recorded in the water. However, the low level of DO recorded in the MS was as a result of the high level of floating aquatic plants such as Nymphea lotus, Salvinia nymphellula and Azolla africana presence in the area. The mean water temperature obtained in Pandam Lake was within the stipulated range as recommended safe for aquatic fauna generally (Esenowo et al., 2014) and .water temperature that can be tolerated by manatee as reported by Powell (1996); Perrin (2001); Akoi (2004) that West African manatees inhabit practically every aquatic habitat that allows them access and meets their thermoregulation requirements of water temperatures greater than 20 degrees Celsius.

Plant species composition, richness and diversity of Pandam Lake: A total of 42 plant species from 23 families were recorded in Pandam Lake (Table 2) during the period of study. The family Poaceae had the highest number of species (22) (30.56\%) followed by the families Mimosaceae and Rubiaceae with 5 (6.94\%) species each. The family Poaceae had the highest number of species $(n=7)$, Cyperaceae had 4 (10.53\%) species, Mimosaceae had 3 (7.89\%) species, while Rubiaceae had one (2.635) species (Figure 1). The vegetation recorded along the banks and on the water surface of the lake were water dependent and commonly found in wetland areas. Majority of these plants were also recorded by Akosim et al, (2007) in Pandam Lake while authors like Adesina et al, (2011) and Obot and Mbagwu (1988) also recorded most of these plants in Jebba and Kainji Lakes. There were also tree species, like Crataeva adansonii, Pterocarpus santalinoides and Morelia senegalensis along the banks of ZU and GU arms of Pandam Lake that were typically riparian forest species, which served as watershed for the Lake and which may also provide resting place for manatee in the afternoon. Moreover, the diverse plant species (38 species from 23 families) were dominated by the Poaceae family. 
Water Parameters and Floristic Composition of African Manatee.....

Table 2: Plant species composition of Pandam Lake

\begin{tabular}{|c|c|c|}
\hline Family & Botanical name & Biological Type \\
\hline \multirow[t]{2}{*}{ Nymphaeceae } & Nymphaea lotus $\mathbf{L}$. & $\mathrm{P}$ \\
\hline & Nymphaea maculate $\mathbf{L}$. & $\mathrm{P}$ \\
\hline \multirow[t]{7}{*}{ Poaceae } & Echinocloa stagnina Retz. P.Beauv & $\mathrm{P}$ \\
\hline & Echinocloa pyramidalis(L.) Hitchc. \& Chase & $\mathrm{P}$ \\
\hline & Vossia cuspidate Griff. & $\mathrm{P}$ \\
\hline & Phragmites spp (Retz.) Steud. & $\mathrm{P}$ \\
\hline & Digitaria horizontalis (Retz.) Pers. & A \\
\hline & Viteveria flavibarbis (Benth.) Stapf & $\mathrm{P}$ \\
\hline & Leersia hexandra Swartz & $\mathrm{P}$ \\
\hline \multirow[t]{2}{*}{ Azollaceae } & Azolla Africana (Desv.) & A \\
\hline & Azolla pinnata & A \\
\hline \multirow[t]{4}{*}{ Onagraceae } & Ludwigia leptocarpa(G.Don)Excell & A \\
\hline & Ludwigia hyssopifolia (G.Don) Excell & A \\
\hline & Ludwigia decurrens Walt. Syn. & A \\
\hline & Jussiaea repens $\mathrm{L}$. & A \\
\hline \multirow[t]{2}{*}{ Polygonacea } & Polygonum lanigerium R.Br. & $\mathrm{P}$ \\
\hline & Polygonum salicifilium & $\mathrm{P}$ \\
\hline \multirow[t]{2}{*}{ Convolvulaceae } & Ipomea aquatica Forsk. & $\mathrm{P}$ \\
\hline & Ipomoea asarifolia (Desr.) Roem. \& Schult & $\mathrm{P}$ \\
\hline \multicolumn{3}{|l|}{ Najadaceae/ } \\
\hline hydrocharitaceae & Najas pectinata Parl. & $\mathrm{P}$ \\
\hline Lemnaceae & Lemna aequinoctialis Welwitsch & $\mathrm{P}$ \\
\hline Ceratophyllaceae & Ceratophyllum demersum $\mathbf{L}$. & $\mathrm{P}$ \\
\hline Alteranthaceae & Alternanthera sessilis(L.) R. Br. ex DC & $\mathbf{A}$ \\
\hline Jussicaceae & Jussica repens & $\mathrm{A}$ \\
\hline Salviniaceae & Salvinia nymphellula Desv. & $\mathrm{P}$ \\
\hline Typhaceae & Typha australis Schum \& Thorn & $\mathrm{P}$ \\
\hline \multirow[t]{2}{*}{ Menyanthaceae } & Nymphoides indica Water-snowflake & $\mathrm{P}$ \\
\hline & Neptunia oleracea water mimosa or sensitive & \\
\hline \multirow[t]{2}{*}{ Mimosaceae } & neptunia & $\mathrm{P}$ \\
\hline & Schrankia leptocarpa & $\mathrm{P}$ \\
\hline Fabeceae & Mimosa pigra $\mathbf{L}$. & $\mathrm{P}$ \\
\hline \multirow[t]{2}{*}{ Lentibulariaceae } & Utricularia charoidea & $\mathrm{P}$ \\
\hline & Diplazium sammatii & $\mathrm{P}$ \\
\hline Capparaceae & Crataeva adansonii & $\mathrm{P}$ \\
\hline Malvaceae & Melochia corchorifolia & $\mathrm{P}$ \\
\hline Papilionaceae & Pterocarpus santalinoides & $\mathrm{P}$ \\
\hline Rubiaceae & Morelia senegalensis Hepper & A \\
\hline \multirow[t]{4}{*}{ Cyperaceae } & Cyperus difformis & A \\
\hline & Pycreus lanceolatus & A \\
\hline & Fimristylis feruginea & $\mathrm{P}$ \\
\hline & Scleria verrucosa & A \\
\hline Sapindaceae & Cardiaspermum halicacabum & A \\
\hline Icacinaceae & Icacinia trichanta & $P$ \\
\hline
\end{tabular}

Note: A means Annual; P means Perennial

This was in agreement with previous studies by Bini et al. (1999); Daddy et al. 1993; Ikenweiwe 2005; Olopade and Eyina, 2017; Dienye 2015) which reported that Poaceae and Cyperaceae are among the best represented families, and are also the most important families in other freshwater ecosystems.

The result further shows that grasses had the highest percentage of $30.95(n=13)$ followed by herbaceous species with $26.19 \%(\mathrm{n}=11)$ while trees had the least percentage of $7.14(n=3)$ (Figure 2). The perennial species were more abundant $(\mathrm{n}=28 ; 66.67 \%)$ than the annual plants $(\mathrm{n}=14 ; 33.33 \%)$. The plant species diversity index (Shannon) was 3.72 .

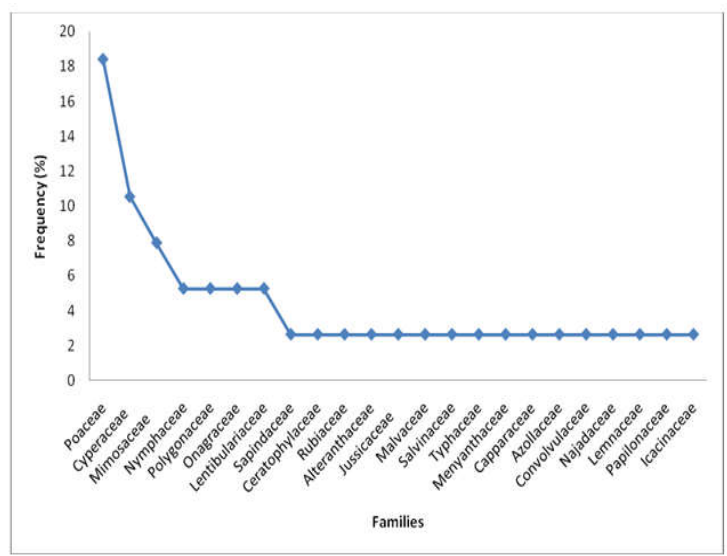

Figure 1: The frequency and percentage of plant species in each family in Pandam Lake 


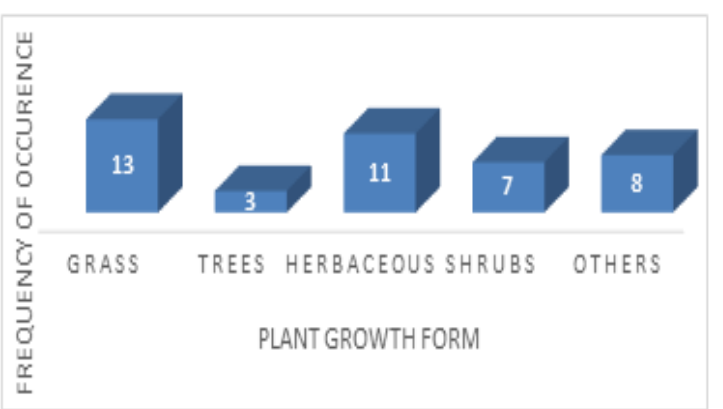

Fig 2: Frequency and percentge frequency of the morphological growth form of plant species recorded in Pandam Lake

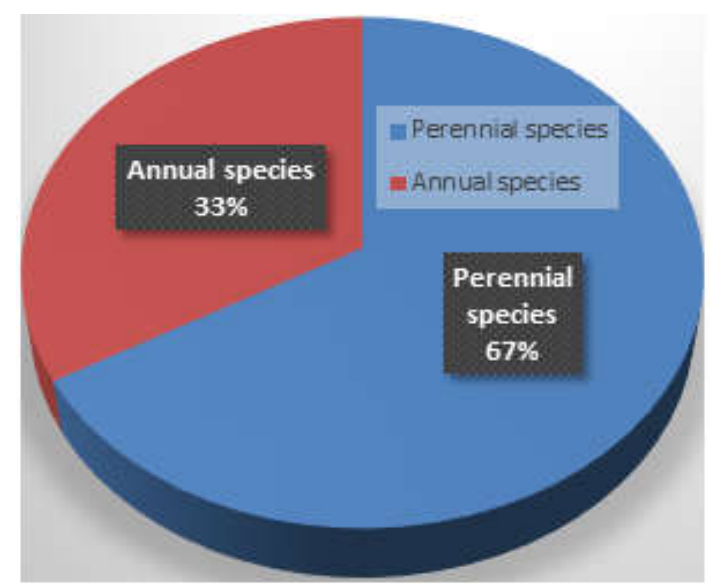

Fig 3: Biological types of plants recorded in Pandam Lake

The diversity index (3.72) of identified aquatic macrophyte species on the lake was within the rang recorded by (Adesina et al., 2007) in Jebba Lake (3.8) which may be due to the flooding of the shoreline areas leading to the increase in biodiversity and also could be as a result of the dungs of manatee, Hippo and many aquatic water birds especially white faced whistling duck that enrich the water and thereby encourage plant growth.. The presence of aquatic macrophytes such as Nymphea species that had their growth apparatus such as rhizomes buried in the soil or seeds dropped on soil surface probably emerged due to the favourable soil condition. This is in agreement with the statement by Obot, (1984) as recorded in Kainji Lake.

Thirteen species of plants recorded in Pandan Lake during this study were known to provide food for manatees across their range in Africa as reported by Powell (1996) and Ofori- Danson (2009); Egwali et. al., (2018). However, manatee feed more on Echinocloa stagnina, Nymphea lotus, Polygonum lanigerium and Echinocloa pyramidalis in that order. This was evidenced in the colour and texture of dungs collected. However, the banks of ZU and GU arms of the Lake were dominated by Echinocloa stagnina, Polygonum lanigerium and sedges, which explained why manatee feeding activities were more concentrated in these areas. Also the dominance of
Nymphea lotus, Salvinia nymphellula, and azolla spp in MS area made it another important feeding area for manatee.

Conclusion: It can be concluded that Pandam Lake in Pandam Wildlife Park can be an ideal habitat or refuge for manatee in the dry and wet seasons as the water parameters in all the three arms of the lake are within tolerable range for manatee to survive while there were diverse plant species that manatee can feed upon in both seasons. Therefore, for effective and sustainable conservation of manatees in Pandam Lake, human activities within and outside the Park should be regulated and monitored regularly.

\section{REFERENCES}

Akoi, K. 2004. The ecology of the West African manatee in the lagoon complex of Fresco. In Fishers and the West African manatee in the Fresco lagoon complex, Cote d'Ivoire, Common property, conflict and conservation. PhD thesis, DICE, University of Kent at Canterbury, Kent, UK, Pp.365

Akosim, C, Kwanga, B.T, Ali, A, and Mamman, G.S. 2007. Flora resources and structure in Pandam Wildlife Park, Pandam, Plateau State, Nigeria. Agricultural Journal 2 (6): 740-747.

Bacchus, C.M, Dunbar, G.S, and Self-Sullivan, C. 2009. Characterization of resting holes and their use by the Antillean manatee (Trichechus manatus manatus) in the Drowned Cayes, Belize. Aquatic Mammals 35(1), 62-71.

Bussi, G., Whitehead, P. G., Bowes, M. J., Read, D. S., Prudhomme, C. P., Dadson, S. J. (2016). Impacts of climate change, land-use change and phosphorus reduction on phytoplankton in the River Thames (UK). Science of the Total Environment, 572, 1507-1519.

Cisneros, K. O., Smit, A. J., Laudien, J., Schoeman, D. S. (2011). Complex, dynamic combination of physical, chemical and nutritional variables controls spatio-temporal variation of sandy beach community structure. PLoS One, 6(8), 23724

De-Domitrovic, Y. Z., Devercelli, M., Forastier, M. E. (2014). Phytoplankton of the Paraguay and Bermejo rivers. Advances in Limnology, 65, 6780

De-Sousa, B. H., Becker, H., Melo, V. M. M. (2016). Influence of river discharge on phytoplankton structure and nutrient concentrations in four 
tropical semiarid estuaries. Brazilian Journal of Oceanography, 64, 37-48.

Deutsch, C.J, Self-Sullivan, C, Mignucci-Giannoni, A.A. 2007. Trichechus manatus. In 2007 IUCN red list of threatened species. Gland, Switzerland: International Union for Conservation of Nature and Natural Resources.

Dodman, T, Ndiaye M, Dagou D, Sarr K. (eds.). 2008. Conservation Strategy for the West African Manatee. UNEP, Nairobi, Kenya and Wetlands International Africa, Dakar, Senegal.

Duong, T. T., Coste, M., Feurtet-Mazel, A., Dang, D. K., Ho, T. C., Le, T. P. Q. (2012). Responses and structural recovery of periphytic diatom communities after short-term disturbance in some rivers (Hanoi, Vietnam). Journal of Applied Phycology, 24(5), 1053-1065.

Ezealor, U. 2002. Critica sites for Biodiversity Conservation in Nigeria. Nigerian Conservation Foundation, Lagos. $110 \mathrm{Pp}$.

Glibert, P. M. (2012). Ecological stoichiometry and its implications for aquatic ecosystem sustainability. Current Opinion in Environmental Sustainability, 4(3), 272-277.

Hang TT, Hoang TTDuong; Kien TN; Quynh TPL, Minh TNL; Duc AT; Anh HL;Cuong TH; Kim DD; Julien N; Didier O; Judith K (2018). Impact of anthropogenic activities on water quality and plankton communities in the Day River (Red River Delta, Vietnam). Environ Monit Assess (2018) 190:67

Irvine, A. 1983. Manatee metabolism and its influence on distribution in Florida. Biological Conservation, 25:315-334.

Isbell, F., Reich, P. B., Tilman, D., Hobbie, S. E., Polasky, S., Binder, S. (2013). Nutrient enrichment, biodiversity loss, and consequent declines in ecosystem productivity. Proceedings of the National Academy of Sciences, 110(29), 11911-11916.

IUCN (2016). Trichechus senegalensis (errata version published in 2016). The IUCN Red List of Threatened Species 2015: e.T22104A97168578.

Keith, D.L. 2015. Trichechus senegalensis (errata version published in 2016). The IUCN Red List of Threatened Species 2015: e.T22104A97168578.
Lancelot, C., Muylaert, K. (2011). Trends in estuarine phytoplankton ecology. In E. Wolanski \& D. Mclusky (Eds.), Treatise on estuarine and coastal science (pp. 5-15). Waltham: Academic Press.

Lathourder, D.R, Darryl, N.J, Balcome, S.R. 2009. Assessing the abundance of freshwater turtles in an Australian landscape. Urban Ecosystem 12: 215231.

Li, Q. P., Dong, Y., Wang, Y. (2016). Phytoplankton dynamics driven by vertical nutrient fluxes during the spring intermonsoon period in the northeastern South China Sea. Biogeosciences, 13(2), 455-466.

Lucas, L., Cloern, J. E., Thompson, J. K., Stacey, M. T., Koseff, J. R. (2016). Bivalve grazing can shape phytoplankton communities. Frontiers in Marine Science, 3, 14.

Mariania, O., Andersen, K. H., Visser, W. A., Barton, A. D., \& Kiørboe, K. (2013). Control of plankton seasonal succession by adaptive grazing. Limnology and Oceanography, 58(1), 173-184.

Nicole, M, Wadja, M.E, and Schmidt, M. 1994. A Preliminary Inventory of Coastal Wetlands of Cote d ivoire. IUCN, Gland Swizerland.

Nomura, F, and Higashi, S. 2000. Effects of food distribution on the habitat usage of a femaleBrown bear Ursus arctos yesoensis in a beech-forest zone of northernmost Japan. Ecological Research, 15, 209-217

Obot, E.A. 2002. Manatee Status in River Benue and River Niger (Nigeria). Unpublished report to Wetlands International, Dakar.

Odewumi, O.S, Agbelusi, E.A and Olusoji- Bello, O.A (2017) Population Status and Encounter rate of West African Manatee (Trichechus Senegalensis) in Pandam Wildlife Park, Middle-Belt Nigeria. Ethiopian Journal of Environmental Studies and Management, 10(7) 877-886

Osakwe, M, and Meduna, A. 1988. Management of the pigmy Hippopotamus and West African manatee in Jos Wildlife Park. The Nigerian Field. 53:175-177.

Packard, J.M, Wetterqvist, O.F. 1986. Evaluation of manatee habitat systems on the Northwestern Florida coast. Coastal Zone Management Journal 14(4):279-310. 
Paczkowska, J., Rowe, O. F., Schlüter, L., Legrand, C., Karlson, B., Andersson, A. (2017). Allochthonous matter: an important factor shaping the phytoplankton community in the Baltic Sea. Journal of Plankton Research, 39(1), 23-34.

Paerl, H.W. \& Huisman, J. (2008). Blooms like it hot. Science, 320, 57-58.

Paerl, H. W., Hall, N. S., Peierls, B. L., \& Rossignol, K. (2014). Evolving paradigms and challenges in estuarine and coastal eutrophication dynamics in a culturally and climatically stressed world. Estuaries and Coasts, 37(2), 243-258.

Powell, J.A. 1996. The distribution and biology of the West African manatee (Trichechus enegalensis Link, 1795). Report to the Florida Marine Research Institute, $1008^{\text {th }}$ Avenue SE,St. Petersburg, Florida 33701. March 1996.

Powell, J.A, Akoi, K. 2006. IUCN Red List Assessment. Draft Report to the IUCN Survival Commission. March 1996.

Read, E. K., Patil, V. P., Oliver, S. K., Hetherington, A. L., Brentrup, J. A., Zwart, J. A., Winters, K. M., Corman, J. R., Nodine, E. R., Woolway, R. I., Dugan, H. A., Jaimes, A., Santoso, A. B., Hong, G. S., Winslow, L. A., Hanson, P. C. and Weathers, K. C. (2015), The importance of lake-specific haracteristics for water quality across the continental United States. Ecological Applications, 25: 943-955.

Reep, R.L; Bonde, R.K., 2006. The Florida manatee Biology. The Quarterly Review of Biology. 81 (4) 410-411.

Sabo, E., Roy, D., Hamilton, P.B., Hehanussa, E.H., McNeely, R, Haffner, G.D (2008). The plankton community of Lake Matano: factors regulating plankton composition and relative abundance in an ancient, tropical lake of Indonesia. Hydrobiologia, 615, 225-235, 1,

Sailley, S. F., Polimene, L., Mitra, A. (2015). Impact of zooplankton food selectivity on plankton dynamics and nutrient cycling. Journal of Plankton Research, 37(3), 519-529.

Save the Manatee (2015) Effects of water Temprature on Manatee migration in Blue Spring State Park.

Seaworld (2002). Introduction to the Sirenians.www.seaworld.org.com. Downloaded on 15 February 2018.

Self-Sullivan C. 2005. Evolution of the Sirenian.

Shaw, J.H. 1985. Introduction to Wildlife Management. McGraw-Hill in New York. 316.

Trimble, M.J., and van Aarde, R.J. (2010) Species inequality in scientific study. Conservation Biology 24(3), 886-890.

Vitousek, P., Porder, S., Houlton, B. Z., Chadwick, O. A. (2012). Terrestrial phosphorus limitation: mechanisms, implications, and nitrogenphosphorus interactions. Ecological Applications, $20,5-15$.

Wehr, J. D., \& Descy, J. P. (1998). Use of phytoplankton in large river management. Journal of Phycology, 34(5), 741-749.

H. Marschner, Mineral Nutrition of Higher Plants, Academic Press, London, 1995, pp. 229-312.

C.S. Bruning-Fann, J.B. Kaneene, The effects of nitrate, nitrite and N-nitroso compounds on human health: a review, Vet. Hum. Toxicol. 35 (1993) 521-538. 